\title{
A Comparative Discourse on Christian and Secular Distinctive \\ Features of Transformational Development \\ Ephraim Yoms ${ }^{1}$ and Nadine Bowers Du Toit ${ }^{2}$
}

\begin{abstract}
The primary objective of this article is to explore some distinctions between Christian and secular views of transformation, characteristics of transformational development and the holistic practitioner. To meet this aim, relevant literature has been explored. The article argues that the Christian's development motivation, goal and process are distinctive. The affirmation of indigenous knowledge; peaceful relationships, self-worth, empowerment and spiritual development are basic characteristics of transformational development. The paper also insists that the attitudes and characteristics of a holistic practitioner play a crucial role in realising these characteristics of transformational development. Understanding the value of this could assist faith-based organization and church-based development agency staff in engaging holistically.
\end{abstract}

Key words: Transformational development, community development practitioner, Theology and Development, Integral Mission, Diaconia, holistic development

\section{Introduction}

The quest for a Christian theological approach to meeting human needs and community development led to the adoption of phrases such as 'holistic ministry', 'transformational development', 'integral mission', 'diaconia' and 'holistic community-based sustainable development'. ${ }^{3}$ This paper is limited to transformational development. This is not to say that the idea of Transformational Development (TD) is regarded as the best alternative strategy for community development, but rather proposed as

1 Ephraim Yoms is affiliated with the University of Stellenbosch and can be contacted at yomsepho@ yahoo.com

2 Nadine is an Associate Professor at the Faculty of Theology, University of Stellenbosch. She can be contacted at nbowers@sun.ac.za.

3 The earlier conceptualisations of the term 'development' perceived it in strictly socio-economic terms. Thereafter the approaches shifted in focus towards human development and environmental sustainability (cf. Rodney, 2009: 2-3).The focus then was on improving the capacity of a national economy, so that the economic condition of a nation would remain more or less stable for a long time. This, in turn, would generate and sustain an annual increase in gross national production (GNP) (Rodney, 2009: 2-3). Christian scholars and development practitioners, however, have chosen to view and understand development in a more holistic sense. 
a holistic Christian framework for addressing human and social need. In fact, the fundamental focus of transformational development is holistic change from a level of human existence that is less than the one envisioned by God to one in which a person is fully human and free to move to a state of wholeness in harmony with God, one another and the environment (Myers, 2011: 3) ${ }^{4}$.This approach insists that equity, justice, human dignity and participation are the bedrock of sustainable development. Focusing on socio-economic empowerment alone (although it is essential) may not be sufficient to meet the range of human needs, which include abstract human needs such as harmonious relationships, dignity and spiritual growth.

This paper is divided into three sections. In the first section, some distinctions between Christian/secular views of transformation are presented. This is followed by the characteristics of transformational development and the third section describes the attitudes and characteristics of a holistic practitioner.

\section{Distinctions between the Christian and secular views of trans- formation}

The Christian motivation for development, its goals and processes of implementation, are key foundations that need to be understood. This paper does not intend to perpetuate a dualism between the secular and the sacred; it is rather an attempt towards understanding the Christian motivation with regards to development as unique.

\subsection{Motivation}

Motivation is one of the key elements that determine the impact of a development project..$^{5}$ In some contexts, the most essential element of secular development is its emphasis on progress, evolution and economic growth. It proposes a process of structural change in such a way that underdeveloped countries could be developed to the level of developed countries (Bowers du Toit, 2010b: 262). The Christian's idea of development, however, is based on the Old Testament concept of shalom or the New Testament concept of the kingdom of God, which are characterised by material well-being, harmony, peace and justice (Bowers 2010b: 266) ${ }^{6}$.

4 This article leans heavily on the legacy of evangelical scholars and practioners such as Bryant Myers, Wayne, Vinay Samuel, Chris Sugden and others who have written on a Christian understanding of development as mission.

5 The motivation for an action may be judged by the level of commitment, support and encouragement toward achieving a set goal. That is, the motivation of an organisation could be seen in the way the human, physical, technical and financial resources are put together and used in supporting and implementing a particular project.

6 This shalom as wholeness also includes spiritual harmony with God and all people in God's world (cf. Eph. 2). 
The foundation of Christian involvement in community development arises from concern for one's neighbour and the sustenance of the love of God (Dudley, 1991: 1). Thus Moffett (2012: 599) makes it right that a commendable and sincere attempt of the secular effort toward improving human conditions cannot be measured with that of Christianity on the basis that the Christian emphasis is both the level of a vertical relationship (with God) and a horizontal one (with neighbours). ${ }^{7}$

Christian development agencies may be involved in social transformation for various reasons; however, their respective ministries are virtually always a natural expression of their faith. Their ministries are in response to the great commandment: total love for God and neighbour. It can also be argued that, while secular donors may provide economic incentives as well as strategies to achieve the donor's or development agency's purpose, the Christian side of social transformation is borne out of personal obedience to Jesus Christ and the desire to have others know and follow Christ (Dudley, 1991: xi-xii).

Secular agencies indeed have sound motives in terms of improving the conditions of the poor; however, the Christian motive goes beyond this. The mission and vision statements of Christian development organisations such as Tearfund and World Vision International may serve as examples of this unique motivation. The latter's mission statement (World Vision International, 2014) is summarised as follows:

To follow our Lord and Saviour Jesus Christ in working with the poor and oppressed to promote human transformation, seek justice and bear witness to the good news of the kingdom of God.

That of Tearfund (n.d.) is:

To serve Jesus Christ by enabling those who share evangelical Christian beliefs to bring good news to the poor. Proclaiming and demonstrating the gospel for the whole person through support of Christian relief and development [...] Seeking at all times to be obedient to biblical teaching.

The above quotes indicate a theological and contextual foundation for Christian motivation. Theologically, Christian motivation emerges from an understanding of the nature of God, humans, the fall, redemption and the kingdom of God. Contextually, it promotes self-reliance in meeting the basic needs of individuals and the community, as well as equity, justice and peace (cf. August, 2010: 48).

This relationship was corrupted by sin, which led to oppression, poverty, injustice and the alienations of individuals, communities and nations (Bowers du Toit, 2010b: 266). 
Furthermore, people's motivation could also be influenced by the person they pledge allegiance to. In that sense, the secular development workers could be working for the donors' benefit or for the benefit of the poor from a humanist perspective. It should be noted that this could also be true of Christian development workers (Elliston, 1989: 170). However, Christian workers ultimately pay allegiance to Christ, with whom they have had a personal encounter. The workers are accountable to the people they serve, to donors, and to God. They regard the poor as individuals with the same rights to dignity and respect regardless of ethnicity, political, or religious value (Myers, Whaites \&Wilkinson 2000: 36). The dominant perspective in the secular development agency is often centred on material, technological and economic progress. In this sense, the future is bright only when there is an increase in the level of employment, a surplus in the budget, and science and technological equipment have been transferred to poor countries for the efficient production of goods and services (Sine, 1987: 3). The Christian perspective, however, is centred on both the immediate future and an eternity in terms of the Kingdom of God (cf. Bowers du Toit, 2010a: 433).

Many secular development agencies may choose to intervene on behalf of others for their benefit, but Christian involvement in social transformation is more than a choice; it is a command. For instance, Dayton (1987: 59) asserts that the world is the object of redemption and the church is the vehicle of that redemption. More so, even though we live in an age of progress and in a scientific and technological world, Christians do not accomplish social transformation through advances in technological and economic progress alone as noted above, but, should recognise the omniscience of the Holy Spirit. By implication a Christian development worker believes that as human beings we cannot overcome our obstacles or achieve success by ourselves. Instead it is through the power of the Holy Spirit who guides and directs our affairs that we can be victorious

\subsection{Goal}

The aims and objectives for engaging in individual or community development (for present or for future purposes) have to be considered before embarking on a development project. Bowers du Toit (2010b: 267) observes that there are structures that hinder progress and rob people of the enjoyment of peace, harmony and justice as intended by God in creation. Therefore, she argues, in agreement with Bragg, that the goal of Christian social transformation is:

To repel the evil structures that exists in the present cosmos and institutes through the mission of the church the value of the kingdom over against the values of principalities and powers. 
This indicates that peaceful and just relations were God's original plan for humanity. However, the entry of sin brought about social disorder. Therefore, Christian engagement in social transformation is to model the good news so as to provide everyone with the opportunity to respond to the commands of the gospel and to live in obedience to it. At the same time, restoring broken relationships, ${ }^{8}$ ensuring justice, peace and hope; and helping communities to recover their true identity and discover their vocation as stewards of God's resources.

\subsection{Process}

Christian and non-Christian development agencies share some practices and systems in the process of development activities. However, Christians have other unique characteristics that may not be found in the secular field. Some of the things Christians and non-Christian development agencies share in common include: "needs assessment, planning, funding, staffing, training, managing, evaluating, making reports, relating to other agencies, social groups, and political structures, coping with cultural and communicational differences and many others similar complex issues" (Elliston, 1989: 173, also see Myers, 2011: 181). Christian involvement in socio-economic development plays a dual role. In the process of improving the material condition of the people, Christian beliefs are introduced to the beneficiary.

For instance, a holistic Christian approach posits that it is God who provided the soil for development and that it is He who is going to help us prosper through development activities (Bornstein, 2002: 9). Moreover, Christian engagement in holistic development is fuelled by a sense of concern, responsibility and privilege (Bosch, 1991: 140). Therefore, Christian involvement in social action is not only unique in terms of evangelism and its understanding of the Kingdom, but even in the way it views and values the people and community it serves. A holistic worker understands that Christ died for the people who will benefit from their development programmes. Their relationships and lives should therefore be characterised by the fruits of the spirit: love, joy, peace, kindness, faithfulness, gentleness, goodness and self-control (cf. Galatians, 5: 22-23).

This suggests that, in any effort, whether economic, political, social or religious, the fundamental issue is geared towards realising a fuller and richer human life. It represents a unique approach to human need by being conscious of God-human relations, justice, equity and dignity (Bragg, 1987: 42). It understands and promotes the spiritual side of human development to balance the socio-economic side. This integrated approach is observable in Bragg's argument (1987: 39), which says that

8 The issue of reconciliation with God, fellow human beings and creation is, however, seen as having eternal significance. 
"transformation is a part of God's continuing action in history to restore all creation to its rightful purposes and relations." Myers (2011: 259) affirms that God's project in the biblical story is to restore the lives of individuals and communities marred by sin so that they can be good, just and peaceful once again.

\section{Characteristics of Transformational Development}

The concept of transformation is not a mere alternative or strategy for community development. Instead, it is a Christian framework for looking at human social change. The characteristics of transformational development in this paper incorporate unique principles that could be used to measure any Christian development praxis.

\subsection{Affirmation of culture, context and indigenous knowledge}

Culture is the way of life and thought of people in a given environment. It can be elaborated on as an integrated system of beliefs, values, customs and institutions that express these beliefs, values and customs (Paredes, 1987: 63). In every society, the peoples' beliefs, values and customs bind them together and give them a sense of identity, security and continuity. These include beliefs about God, reality, the ultimate meaning of the values relating to what is true, good, beautiful and normative, including norms on how to behave, relate to others, talk, pray, dress, work, play, trade, farm and many others. This culture relates to institutions that express beliefs, values and customs that relate to governance, law courts, churches, families, schools, hospitals, factories, shops, unions, clubs and others (Paredes, 1987: 63).

On this direction, transformation is not about changing the way people think and behave in a community. It is about being aware that community customs are linked together, to the extent that, if there is going to be change in one area of life, many other areas will change as well (Hiebert, 1989: 86-87).Therefore, if new ideas are to be introduced, it needs to be done in such a way that it can easily be adopted by the beneficiaries. The holistic practitioner needs to plan and use resources beneficiaries are familiar with. Anacleti(2002: 71) notes that for people to participate in decisions that affect their lives, they must start with what they know and what most people regard as their own culture and values. This is because they are guided by their cultural principles and values. As such, it is mandatory to study the local culture in an effort to realise that community development is not optional. Anacleti (2002: 170) adds that:

[p] eople are not developed, they develop themselves and for people to develop themselves they have to be convinced that the changes envisaged will not be a mere experiment with their lives, but will actually mean a change for better 
This is in contrast with the modernisation way of thinking, in which indigenous culture is seen as a hindrance to development. On this note, Bragg (1987:45) reminds us that transformation affirms indigenous culture because all cultures are part of God's gift to humanity. For Christ to enter into Jewish social and religious life, shows that he (Christ) honours human culture. Christ's attitude here is an eye opener to the fact that all cultures have intrinsic values that can be redeemed and used as a basis for social transformation.

This suggests that valuing people's culture in development efforts is essential to the planning and implementation of all development. These cultures will serve as instruments for promoting social justice, equality, sustainability, identity and dignity for all members of the community. Myers (2011: 205) explains that it is important for a practitioner to respect the community's story, because the history of the community could unveil the community's real problems and present a possible way forward. As for the community dwellers, they feel their story is valuable as long as someone is able to listen to it (Myers, 2011: 206).

To value and respect people's cultures and indigenous knowledge are both theological and contextual in Christian community development. Hiebert (1989: 75) reveals that being both theological and contextual are two dimensions of Christian development. It is theological because Christians' vision, mission and motivation of development emerge out of their fundamental understanding of the nature of God, humans, the fall, redemption and the kingdom of God. By being contextual the Christian finds it easier to build and encourage those they have developed, regardless of their cultural, social, religious, and racial differences. That is, development must be done with the context of the people in mind.

\subsection{Just and peaceful relationships}

Christian development practitioners understand and promote just and peaceful relationships as one of the means of achieving holistic development of the human community. Bragg (1987: 43), for instance, points out that transformation provides a ground where human beings, no matter their race, religion or nationality, may live a fully human life, freed from domination and oppression by other people. In addition, development is a matter of human relations and justice (right relationship with God and God's people) in which domination, oppression and exploitation are abnormal (Robinson, 1994: 318).

This means that unjust relationships are the root causes of disparities and inequalities in society. In this sense, true development is the development of people, the release of people from their enslaved conditions so that they can actively participate in the process of making decisions that affect their lives and labour (Robinson, 1994: 318-319). In the account of the fall in Genesis, the right relationship with 
God, fellow human beings and nature were distorted. A healthy relationship with God is the basis of all other relationships and these relationships are an integral part of holistic development (Bragg, 1987: 44). Migliore (2004: 267-268) adds that the missional activity of the church is to foster a just and inclusive community in which members use their ministerial gifts for the well-being of the whole. Myers (2011: 181) also explains the levels of these relationships as relationship with the triune God, relationship with oneself and relationship with the community.

This means that society will be good if all relationships are restored. Moltmann (1993: 134) comments that "every relationship to another life involves the future of that life, and the future of the reciprocal relationship into which one life enters with another". For instance, Christian hope is a living hope and is connected in relationships with God, oneself and others in the community. When this framework of relationships ceases to exist, "hope" will be invalid. A cordial relationship unites affection with respect. In a positive relationship, both parties experience respect, acceptance, trust, freedom and happiness.

Therefore, when human relationships are cordial, oppressive attitudes can be abolished, and when what makes a person truly humane emerges it can be affirmed that transformation is taking place in both the individual and the community. Moltmann (1993: 116) concludes that, until then, "the new man, the true man, the free man [the transformed man] is the friend". In the same way, transformation that is founded on a just and peaceful relationship allows people to trust and live with one another as spacefriends while sharing privileges and opportunities. Such a transformation is healing and joyous. Church educators should endeavour to facilitate the healing process in communities living in desperation by speaking and acting prophetically (cf. Brueggemann1984: 26).

\subsection{Dignity and self-worth}

Promoting human dignity and self-worth is another important goal of TD (Bragg, 1987: 42). In other words, affirmation of people's dignity and self-worth is one of the significant tasks of the transformational agenda, because people need to have self-esteem to be fully human. This is because the experiences most poor people go through tend to make them feel as if they are valueless, unproductive, hopeless and helpless. When they are transformed it will give them a sense of belonging in society. Myers (2011: 178) states that both the poor and non-poor need to know who they are and the purpose for which they were created. In that case, restoring the identity and vocation of the poor and non-poor becomes a vital indication of human transformation.

The fact that men and women, poor and non-poor, are made in God's image says something about their identity. For God to have loved them and sent the Son to come 
and die for them signifies their human dignity. To give them gifts that contribute to their human well-being shows the importance of their vocation (Myers, 2011: 178). Along these lines, Myers (2011:179) emphasises that:

i. A transformed, dignified person transforms [his or her] environment.

ii. People, not money, or programmes, transform the world.

iii. Genuine steps to transforming people are not all about transferring resources, but include recovering lost dignity and identity.

iv. People must be shown that their human dignity and identity are intrinsically related to God in Christ.

v. God's purpose in human history is redemptive.

The point is that, on the one hand, social, political and economic transformation of the poor is essential for human well-being. On the other hand, a transformational agenda declares to people that they are made in the image of God with potential and abilities. Through the salvific work of Christ they can regain and fulfil the purpose of their creation (Myers, 2011:180). This coincides with Burkey's (1993: 56) perception that the essence of development is to ensure that people are able to increase their level of self-confidence, pride, initiative, creativity, responsibility, and co-operation. In the absence of these elements, all efforts towards poverty alleviation will be difficult or impossible.

Similarly, theological and non-theological scholars within the discipline of development have argued that, beside the material human needs there also are abstract needs. These are not visible, yet they are very crucial for human survival. Burkey (1993: 3), for instance, refers to such human needs as emotional security and mental rest. This study holds that these factors have to do with a sense of who people are, what they are worth and the purpose for which they are created (Samuel \& Sugden, 1999: 238). This is because it is possible for people to have the material things they need for sustenance but still lack self-respect, peace, love, protection, free choice and someone to listen to their story. They can be emotionally depressed because of isolation. People who have a good sense of identity and dignity know that they are not expected to treat others or be treated as less important human beings (Samuel \& Sugden, 1999: 246). For this reason, Bragg (1987: 42) sees development as people gaining control over their environment and destiny with dignity and self-worth.

It is, therefore, reasonable to argue that those individuals, families and communities with a good sense of identity and dignity experience freedom, justice, love and peace. In such an environment, care is given to the poor and weak, women and children; people respect and are respected, and people love and are loved. Hughes and Bennett (1998: 79) argue that this kind of life was practised and taught by Jesus and serves as a model for his followers worldwide to break down every social barrier that robs people of a sense of identity and dignity. Christians have their identity 
in God through the finished work of Christ on the cross and are equipped with spiritual gifts to serve in the household of faith.

\subsection{Empowerment and self-reliance}

Another significant characteristic of transformation is empowerment with an attitude that supersedes the idea of superiority and inferiority. The worldly concept of power does not create such an environment; rather, "it has always been in tension with the power of the servant, the power of love and of the finer aspect of justice" (Christian, 1999: 185). As such the desire to become "bigger, better, faster, prettier, stronger, and smarter" has always been a driving force (Oladosu, 2010: 56). By implication powerlessness is viewed as incapability which hinders development, especially when people lack economic and social status, and political and religious power (Speckman, 2007: 249-251). In this sense, empowerment is a people-enablement process for tackling poverty. The element of empowerment therefore is the control over economic resources and the ability of the poor to articulate and assert themselves (Rahman, 1993: 205).

Ajulu (2001: 142) perceives empowerment as a three-tiered integral process focusing on the individual, community and structure. The integral empowerment process addresses all human needs, be they social, material or spiritual. It also addresses the community as a complete entity for the rich, poor and those in between. Lastly, it addresses a range of structures that affect individual and community development. ${ }^{9}$ Thus, collective abilities are needed of individuals in a given community to take charge of identifying and meeting their own needs as households, communities, organisations, institutions, societies and nation (Rowlands, 1996: 90). It is not part of God's plan that power only resides with the "upper class" while the "lower class suffers". God is not in favour of dependency ,and human development should free a person from depending on others (Speckman, 2007: 253).

Synder (1995: 6) explains that empowerment is the state of persons (women and men) being enabled to take their destiny into their own hands. Synder (1995: 6) outlines three elements of empowerment in development as follows: the first is economic empowerment, which has to do with access to assets like land, capital and technologies that can produce income. The second has to do with basic human necessities such as education and health services, clean water, fuel and shelter. Participation in decision-making is the third element. The above list indicates that participants must be empowered for the sustainability and effectiveness of any development programme or project.

Nevertheless, empowerment would require the development of skills and abilities to make decisions regarding community development programmes. Individuals

9 Such obstacles may include as culture, tradition, politics, governance, institutions and organisations. 
and communities need to own the vision and value their work. As Gilchrist and Taylor (2011: 22) stress, "[e]very person has capabilities, abilities and gifts. Living a good life depends on whether those capabilities can be used, abilities expressed and gifts given. If they are, such people will feel valued, feel powerful and be wellconnected to the people around them". This belief is also held by Swanepoel and De Beer (2011: 52), who argue that people must be empowered with the necessary information and freedom to decide on what they want.

The above analysis of empowerment shows that people's power comes ultimately from self-reliance, especially when they are able to meet their material and emotional needs themselves. That is, self-reliance means confidence, reliance primarily on one's own resources, human and natural, and the capacity for autonomous goal-setting and decision making. Physical, economic, social and political incapacity makes a person dependent on others. Equal access to material goods and opportunities to fulfil basic needs are essential characteristics of development. By implication, dependency implies inequality, which is against the will of God. Interdependence is rather a biblical injunction, which is an essential aspect of human life. God intends humans to live in community, not in isolation (Robinson, 1994: 319-320). In this way, development is essentially the removal of the conditions of dependency. Nevertheless, self-reliance must lead people to acknowledge God as the source of their lives. It must lead them to put their confidence in Him whose goodness and mercy are reliable and whose promises cannot fail. ${ }^{10}$

Self-reliance also leads to sustainability. A self-reliant individual or community does not depend on external help without building capacity. Bragg (1987) reveals that it is God's intention for us to have adequate life-sustaining goods and services, and that development must enhance sustainability of the community's economic, social and environmental resources. Development projects must continue even when the change agent is no longer in the project area. Consequently, any form of development that does not lead to self-reliance must be avoided. The people should own the project, rather than feel that it was imposed on them by some authority.

\subsection{Spiritual development}

Whilst empowerment and self-reliance are important for human well-being, they are not complete without recognition of the spiritual dimension of life. The element of spirituality completes the idea of holistic human development. Of course, it could be expected that government and non-governmental organisations that are involved in community development would focus on people's intellectual, physical and social wel-

10 Jeremiah, 39: 18 tells us that God alone gives perfect peace to the troubled, healing to the sick, provision to the poor, hope to the hopeless, strength to the weak, faith to the fearful, and rescue to the oppressed. 
fare at times to the neglect of their spiritual condition. It would be a great disappointment if faith-based development practitioners and institutions also neglect spirituality.

Of course, the ultimate goal of development is human well-being. ${ }^{11}$ Ignorance, exploitation, socio-cultural constraints and institutional structures are major factors that rob people of freedom by holding back access to social, economic and political power and rendering them voiceless (Bragg, 1987: 43). Poor people are mostly not free in the physical, material, spiritual and social areas of their lives. Transformation therefore involves the whole person, mind, body and spirit in any development effort.

Moreover, a transformational approach seeks to address the issue of sin, which leads to corruption, greed, conflicts, inequality and exploitation, all of which are contrary to God's plan for people (Davis, 2009: 92-93). Furthermore, evil is not only in the human heart, but also in social structures (Bowers, 2010b: 266). Within a transformational approach, unjust economic relations, political imbalances, social misappropriation and religious or cultural domination, are addressed. In this case, 'changed' people will be able to "discover their true identity as children of God and recover their true vocation as faithful and productive stewards of God's gifts for the well-being of all" (Myers, 2011: 3, 17).

Emphasis on spiritual development as a characteristic of development cannot be overemphasised. Korten (1990: 168) reminds us that people's spiritual growth and nourishment are among the important responsibilities of the church. That is because the church's role is to teach people in society the use of power, values, brotherhood, peace and the ability to live in harmony with one another. By implication, this approach can lead to the elimination of unjust structures, the tendency for corrupt practices, exploitation and misuse of power. It can be argued theologically that human beings have always been in search of meaning and purpose in their lives. This search can bring them a sacred connection. The connection gives people insight into the meaning and significance of their lives and the integration of all aspects of their being (Nash \& Stewart, 2002: 17). This makes spirituality an important aspect of human need for sustainable well-being. ${ }^{12}$

Sometimes people reject development efforts because of their cultural and religious orientation. As an illustration of the importance of spirituality, at other times it could be discovered that people prefer magic charms to development efforts (Myers, 2011: 142). What people believe about the world and its relationship to their

11 Such as having enough food, assets, a job, being in good physical condition, having self-respect and dignity, living in peace and harmony with family and community, as well as having access to justice and security

12 For example, it is in the spiritual dimension that a person strives for transcendental values, meanings, experience and development and for union with the imminent, supernatural powers that guide people and the universe for good and evil (Nash \& Stewart, 2002: 15-16). 
well-being shapes the way they respond to everything, including poverty (Hughes \& Bennett 1998: 133-134). This strengthens the role that spiritual sensitivity plays in the initiation and management of development programmes and projects (Nash \& Stewart, 2002: 19). Therefore, when a person is transformed, spiritual growth begins, the Holy Spirit indwells the believer (John, 14:16-17), and the old nature is replaced with the new (2 Corinthians, 5: 17). Therefore, people's spiritual transformation is crucial. Hughes and Bennett (1998: 133) elaborate:

Even if a community develops economically, politically and socially, unless it encounters God in Jesus, it will still be afflicted by the poverty of not knowing God, [...] this spiritual poverty will sooner or later lead to other forms of poverty as other forms of sin such as greed begin to dominate.

This quote shows that the freedom to grow in relationship with God and live out values appropriate to the Kingdom of God is crucial for sustainable development (Byworth, 2003: 109). Transformation therefore, frees people from slavery to other people, institutions, beliefs, oppressive systems and ignorance and paves the way to political, social, economic and spiritual freedom (cf. Bragg, 1987: 43).

\section{The holistic practitioner}

The holistic practitioner's attitudes and character play an important role in achieving holistic development. These unique qualities of Christian development are crucial to achieving transformation.

\subsection{The attitudes of a holistic practitioner}

The role of a holistic practitioner is to help in fostering good relationships in the community. Therefore, the fruits of the spirit, such as love, joy, peace, patience, kindness, goodness, faithfulness, gentleness and self-control, are key attitudes of a holistic practitioner (Galatians 5:22-23). In addition, a holistic transformational practitioner must learn to be a good neighbour, i.e. to love and to be kind to neighbours. S/he must have the willingness to be a learner. No or little transformation will take place if the worker and beneficiaries are not ready to learn from one another (see Myers, 2011: 219).

The holistic practitioner's spiritual and moral life must go hand-in-hand with professionalism. Obedience to simple instructions helps workers to maintain their integrity and ensures a true sense of stewardship. A Christian who sets apart and cleanses him/herself for God's service must maintain the evidence of inner transformation that is characterised by a life of purity, moral integrity, and holy living. His or her thoughts and actions must be expressed in an outward life of goodness and godliness (Samaan, 1989: 131). 


\subsection{The characteristics of a holistic practitioner}

Understanding the characteristics of a holistic practitioner is crucial, since the focus of TD is on the physical and spiritual transformation of the people. Development workers may have well-designed plans and strategies on how to carry out successful projects, but that may not be adequate if they do not clearly understand what is desired of a holistic practitioner. The first important characteristic of a holistic practitioner is to be a born-again Christian.That is, he or she needs to know and experience God in an intimate relationship, growing towards Christ-likeness while doing the work of God (Samaan, 1989: 131).

Besides being born again, knowledge of the Bible is crucial for effective service. The Word of God is an infallible manual for a holistic practitioner; it teaches how to live for God and to serve him. It is only by careful, devotional Bible study that a worker will not fall into public disgrace (cf. 2 Timothy, 2: 15). Theological and biblical knowledge are key tools that a holistic practitioner can use to handle the physical and spiritual challenges that may be encountered in the project area.

However, being a Christian and a professional cannot be separated in the development approach. Professionalism can fuel a holistic practitioner to success. A Christian worker who wants to make an impact in the project area must have the technical knowhow, skills, strategies and knowledge of the dynamics of needs in the project area. In other words, since the Christian approach is holistic, the Christian worker's knowledge must be holistic too. Knowledge of social science and of scripture is important for engaging in transformational development (Myers, 2011: 225).

It takes a humble and compassionate practitioner to relocate to the project area so as to carefully study and become intimately familiar with the social and cultural system of the communities where s/he will serve. Burkey (1993: 5) echoes Chambers' analysis of the flaws of most people who are keenly concerned with rural development but who are neither rural nor poor. Often the strategies for project conception and implementation they use do not represent the aspirations and interests of the targeted communities.

\section{Conclusion}

The paper argues that holistic Christian ministry has unique characteristics. Upholding culture and indigenous knowledge is an important characteristic of transformational development. People's way of life, beliefs, values and customs, as well as the institutions that express them, must be respected. The holistic practitioner must communicate the gospel of word and deed within the context of the beneficiaries, and ensure that indigenous knowledge is valued. Just relations must be the focus of development, as unjust relations are the root causes of the inequalities in society. Thus, the affirmation of people's dignity and self-worth is mandatory for a transformational 
agenda. People need self-esteem, not dependency - which implies inequality, to be fully human. Therefore, all people should be empowered intellectually, physically, mentally and spiritually to enjoy the God-given blessings of creation. Individuals or communities must be free to grow in their physical, mental, social and spiritual life.

\section{References}

Ajulu, D. 2001. Holism in development: An African perspective on empowering community. Monrovia: MARC.

Anacleti, 0. 2002. Research into local culture: Implication for participatory development, in D. Eade (ed.). Development and culture. Oxford: Oxfam Publishing. 168-173.

Bowers, N. 2010. Moving from development to social transformation: Development in the context of Christian mission, in I. Swart, et al. (eds.). Religion and social development in post-apartheid South Africa. Stellenbosch: SUN Press. 261-274.

Bragg, W.G. 1987. From development to transformation, in V. Samuel \& C. Sugden (eds.). The church in response to human need. Grand Rapids: Eerdmans. 20-51.

Burkey, S.1993. People first: A guide to self-reliant participatory rural development. New York: Zed Books.

Byworth, J. 2003. World Vision's approach to transformational development: Frame, policy, and indicators. Transformation, 20(2): 102-114.

Davis, R. 2009. What about justice? Toward an evangelical perspective on advocacy in development. Transformation: An International Journal of Holistic Mission Studies Volume 26 No 2 April 2009. 89-103.

Edwards, M. \& Sen, G. 2000.NG0s, social change and the transformation of human relationship: A 21st century civic agenda. Third World Quarterly, 21(4):605-616.

Erasmus, J.C. 2005. Religion and social transformation: A case study from South Africa. Transformation: An International Journal of Holistic Mission Studies, Transformation, vol. 22, no. 3, 2005, 139-148

Gilchrist, A. \& Taylor, M. 2011.The short guide to community development. Bristol: The Policy Press.

Hiebert, P. 1989. Anthropological insights for whole ministry, in E.J. Elliston, (ed.). Christian relief and development: Developing workers for effective ministry, Dallas: World Publishing.75-92.

Hughes, D. \& Bennett, M. 1998.God of the poor: A biblical vision of God's present rule. Cumbria: Om Publishing.

Korten, D.C. 1990. Getting to the 21stcentury: Voluntary action and the global agenda. West Hartford: Kumarian Press.

Migliore, D.L. 2004.Faith seeking understanding: An introduction to Christian theology. 2ndEdition. Grand Rapids: Eerdmans.

Moltmann, J. 1993. The church in the power of the spirit: A contribution to messianic ecclesiology. Minneapolis: Fortress Press.

Myers, B.L. 2011. Walking with the poor: Principles and practices of transformational development. New York: Orbis Books. 
Nash, M. \& Stewart, B. 2002.Spirituality and social care: Contributing to personal and community well-being. Philadelphia: Jessica Kingsley Publishers.

Oladosu, S.B. 2010. An evaluation of James and John's request in Mark's Gospel in the annals of servant leadership in Nigeria experience.UMCATC Journal of Theological Studies, 7:56-74.

Paredes, T. 1987. Culture and social change, in V. Samuel, C. Sugden (eds.). The church in response to human need. Grand Rapids: William B. Eerdmans Publishing Company. 62-84.

Robinson, G. 1994. Christian theology and development.The Ecumenical Review, 46(3):316-321.

Rodney, W. 2009.How Europe underdeveloped Africa. Abuja: Panaf Publishing, Inc.Abuja: POWA Complex.

Samaan, L.E. 1989. Spiritual formation relief and development workers, in E.J. Elliston (ed.). Christian relief and development: Developing workers for effective ministry. Dallas: World Publishing. 129-143.

Samuel, V. \&Sugden, C. 1999. Mission as transformation: A theology of the whole gospel. Carlisle: Paternoster Publishing.

Sine, T. 1987. Development: Its secular past and its uncertain future, in V. Samuel \&C. Sugden (eds.). The church in response to human need. Grand Rapids: Eerdmans. 1-19.

Speckman, M.T. 2007. A biblical vision for Africa's development. Pietermaritzburg: Cluster Publications.

Swanepoel, H. \& De Beer, F. 2011. Community development: Breaking the cycle of poverty.5thEdition. Lansdowne: Juta and Co Ltd.

Synder, M. 1995. Transforming development: Women, power and politics. London: Intermediate Technology Publications. 